\title{
Erratum to: Biotic factors in induced defence revisited: cell aggregate formation in the toxic cyanobacterium Microcystis aeruginosa PCC 7806 is triggered by spent Daphnia medium and disrupted cells
}

\author{
Sven Becker - H. C. P. Matthijs - Ellen van Donk
}

Published online: 31 May 2011

(C) Springer Science+Business Media B.V. 2011

\section{Erratum to: Hydrobiologia (2010) 644:159-168 DOI 10.1007/s10750-010-0109-y}

It has been established beyond doubt that the original publication of this article does not present the correct information on authorships, on exact location where the work was done and on the funding agencies to be acknowledged. The correct information has thus been published above and below and should be treated as definitive by the reader.
The online version of the original article can be found under doi:10.1007/s10750-010-0109-y.

\section{S. Becker · E. van Donk $(\bowtie)$}

Department of Aquatic Ecology, Netherlands Institute of Ecology (NIOO-KNAW), Rijksstraatweg 6,

3631 AC Nieuwersluis, The Netherlands

e-mail: e.vandonk@nioo.knaw.nl

\section{H. C. P. Matthijs}

Department of Aquatic Microbiology, Institute for Biodiversity and Ecosystem Dynamics, University of Amsterdam, Science Park 904, 1098 XH Amsterdam, The Netherlands

\begin{abstract}
Acknowledgements The authors are grateful to two anonymous referees who provided comments on a previous version of this article. Scott Taylor evaluated the English language of the manuscript. The practical work was done at the Department of Aquatic Ecology, Netherlands Institute of Ecology, Nieuwersluis, the Netherlands, with a grant from NIOO-KNAW.
\end{abstract}

